\title{
INTELLIGENCE QUOTIENT (IQ) BERPENGARUH TERHADAP PERILAKU SEKSUAL BERISIKO PADA REMAJA DI JAKARTA PUSAT
}

\author{
Veronica Yeni Rahmawati ${ }^{1 *}$, Jehan Puspasari ${ }^{1)}$ \\ 1) Program Studi DIII Keperawatan, STIKes RS Husada Jakarta, Jakarta Pusat
}

e-mail:vero@stikesrshusada.ac.id

\begin{abstract}
ABSTRAK
Masalah perilaku seksual berisiko pada remaja dari tahun ke tahun dilaporkan mengalami peningkatan yang signifikan, hal ini terlihat dari usia pacaran yang masih remaja. Status intelegensi yang masih terbilang rendah pada remaja, dapat menyebabkan masalah kesehatan khususnya perilaku menyimpang pada remaja. Penelitian ini bertujuan untuk mengetahui hubungan antara Intelligence Quotient (IQ) dengan perilaku seksual berisiko pada remaja di Jakarta Pusat. Penelitian ini menggunakan analitik kuantitatif dengan desain cross sectional. Pengambilan sampel menggunakan teknik purposive sampling sehingga didapatkan sampel 147 responden. Responden penelitian adalah remaja yang berusia 17-19 tahun di Jakarta Pusat. Instrumen yang digunakan adalah data primer (kuesioner) dan data sekunder (hasil tes IQ oleh lembaga test psikologi yang legal). Analisis data yang digunakan yaitu uji statistik bivariat menggunakan chi square dan uji statistik multivariat menggunakan regresi logistic. Hasil penelitian menunjukkan terdapat hubungan yang signifikan antara Intelligence Quotient (IQ) dengan perilaku seksual berisiko pada remaja di Jakarta Pusat ( $\mathrm{p}=0,000$, OR 22, 95\% CI 0,561-0,801). Peneliti merekomendasikan peran institusi pendidikan mengembangkan daya kreativitas remaja dengan menggunakan kemampuan kognitif untuk meningkatkan kecerdasan intelektual agar terhindar dari perilaku seksual berisiko.
\end{abstract}

Kata kunci : Intelligence Quotient (IQ), Kognitif, Perilaku seksual berisiko, Remaja,

\section{ABSTRACT}

The problem of risky sexual behavior among adolescents from year to year is reported to have increased significantly, this can be seen from the dating age which is still adolescents. Intelligence status which is still relatively low in adolescents can cause health problems, especially deviant behavior in adolescents This study aims to determine the relationship between Intelligence Quotient (IQ) and risky sexual behavior among adolescents in Central Jakarta. This research used quantitative analytic with cross sectional design. Sampling using purposive sampling technique in order to obtain a sample of 147 respondents. Research respondents were adolescents aged 17-19 years in Central Jakarta. The instruments used were primary data (questionnaires) and secondary data (IQ test results psychological test agency). The data analysis used was the bivariate statistical test using chi square and the multivariate statistical test using logistic regression. The results showed that there was a significant relationship between Intelligence Quotient (IQ) and risky sexual behavior among adolescents in Central Jakarta ( $p=0.000$, OR 22, 95\% CI 0.561-0.801). Researchers recommend the role of educational institutions in developing adolescent creativity by using cognitive abilities to increase intellectual intelligence to avoid risky sexual behavior.

Keywords : Adolescents, Cognitive, Intelligence Quotient (IQ), Risky sexual behavior 


\section{PENDAHULUAN}

Remaja adalah sosok individu dan generasi muda yang sedang dalam masa perkembangan. Masa perkembangan ini merupakan masa perubahan atau peralihan dari masa remaja menuju batas kedewasaan yang meliputi perubahan biologik, psikologik, dan sosial. Perubahan tersebut menyebabkan perubahan perilaku pada mahasiswa. Namun seringkali perilaku yang dilakukan mahasiswa ini tidak mencerminkan suatu kedewasaan. Salah satu tindakan yang akhir-akhir ini mendapat banyak sorotan dan dijadikan sebagai bahan penelitian adalah perilaku seksual berisiko di kalangan mahasiswa. Situasi ini terjadi dikarenakan mahasiswa kurang mengetahui tentang dampak dari perilaku seks berisiko (Viner, Allen \& Patton, 2017).

Usia remaja merupakan tahap pertumbuhan dan perkembangan yang ditandai dengan terjadinya proses transisi dari masa anak-anak menjadi dewasa. Pada masa ini berbagai perubahan terjadi secara signifikan baik secara fisik maupun psikososial. Perubahan yang terjadi secara fisik antara lain perubahan tinggi badan, berat badan dan perubahan hormonal sedangkan perubahan yang terjadi secara psikososial antara lain perubahan emosional, kognitif dan social. Perubahan-perubahan tersebut dipengaruhi oleh berbagai faktor antara lain faktor internal dan faktor eksternal. Faktor internal yang mempengaruhi perubahan tersebut seperti pengetahuan, gaya hidup, pengendalian diri, aktivitas sosial, rasa percaya diri, dan usia. Sedangkan faktor eksternal yang mempengaruhi perubahan tersebut antara lain kontak dengan sumber informasi kesehatan, social budaya, nilai dan norma sebagai pendukung social untuk perilaku tertentu dan faktor lingkungan terdiri dari keluarga (pola asuh, komunikasi, peran, sosioekonomi dan pendidikan orang tua) serta teman sebaya. Hal tersebut memerlukan suatu pemantauan dan pengawasan dalam menghadapi perubahan tersebut sehingga tidak terjadi pola perilaku menyimpang di usia pertumbuhan dan perkembangan remaja (Jaworska \& MacQueen, 2015). 
Usia remaja berdasarkan $\mathrm{BKKBN}$ menjadikan populasi ini merupakan terbanyak dibandingkan dengan agregat usia lain. WHO tahun 2015 menjelaskan bahwa populasi remaja di dunia kurang lebih seperlima dari jumlah total penduduk yang ada atau sebesar 1,2 milyar jiwa. Di Indonesia berdasarkan sensus penduduk tahun 2015 terdapat sebanyak $18 \%$ atau sebanyak 43,5 juta penduduk berusia remaja (Kemenkes, 2015). Lebih lanjut jumlah remaja terbanyak di DKI Jakarta yaitu 24,8\% diikuti Jawa Tengah $24,7 \%$ dan Jawa Timur 23,2\% (Bappenas, 2013). Sementara di Jakarta Pusat yang merupakan wilayah dari DKI Jakarta menyebutkan bahwa populasi remaja terdapat kurang lebih $21 \%$ dari total jumlah penduduk di DKI Jakarta (BPS, 2018).

Berdasarkan data tersebut dapat diasumsikan bahwa remaja merupakan populasi yang memiliki peran sangat penting terhadap perkembangan suatu wilayah namun remaja juga dapat menyumbangkan suatu masalah salah satunya masalah kesehatan (Apsari \& Purnamasari, 2017).
Masalah kesehatan yang terjadi pada usia remaja bervariasi bahkan masalah yang timbul bisa didapatkan dari dampak perilaku menyimpang. Survei kesehatan dunia melaporkan terdapat sebanyak $68,9 \%$ dengan perilaku berisiko diantaranya perilaku merokok, perilaku seksual berisiko, alcohol, tawuran, kecelakaan bermotor dan obesitas pada remaja perempuan (Kipping et al., 2014).

Pola perilaku yang menyimpang sangat dipengaruhi oleh era zaman modern yang menggiring remaja untuk mengeksplorasi hal-hal baru termasuk perilaku menyimpang. Salah satu bukti konkritnya yaitu adanya media internet yang dapat digunakan oleh remaja untuk mengakses berbagai situs salah satunya situs yang mengandung konten pornografi. Ketika seorang remaja terus-menerus terpapar tayangan atau konten yang mengandung unsur pornografi maka remaja akan merasa tertantang untuk melakukan hal serupa secara nyata seperti berhubungan seksual dengan teman perempuan atau laki-laki (Epstein et al., 2014). 
Masalah perilaku seksual berisiko pada remaja dari tahun ke tahun dilaporkan mengalami peningkatan yang signifikan, hal ini terlihat dari usia pacaran yang masih remaja. Perilaku seksual berisiko yang ditunjukkan remaja dalam konsep ini adalah berpegangan tangan dengan lawan jenis, berpelukan, cium bibir dan meraba/ diraba. Di Indonesia, berdasarkan Survei Demografi dan Kesehatan Indonesia (SDKI) tahun 2017 ditemukan $45 \%$ remaja perempuan dan $44 \%$ remaja laki-laki yang berpacaran di usia 15-17 tahun. Secara garis besar di usia remaja memiliki potensial tinggi untuk melakukan perilaku seksual berisiko dikarenakan usia remaja merupakan karakteristik usia yang ingin mencoba hal-hal baru sedangkan life skills belum mencukupi.

Perilaku seksual berisiko dapat juga dilihat dari hubungan seks pra nikah remaja. Menurut SDKI tahun 2017, hubungan seks sebelum menikah meningkat dari tahun 2012 hingga tahun 2017. Pada tahun 2017 SDKI menunjukkan bahwa sebanyak $14,6 \%$ remaja pernah melakukan hubungan seksual di luar nikah. Perilaku seksual yang ditunjukkan remaja saat ini adalah berpegangan tangan dengan lawan jenis sebanyak 64\% remaja putri dan $75 \%$ remaja putra, berpelukan sebanyak $17 \%$ remaja putri dan $33 \%$ remaja pria, cium bibir sebanyak $30 \%$ pada remaja putri dan $50 \%$ pada remaja pria dan meraba/ diraba sebanyak 5\% remaja putri dan $22 \%$ remaja pria (SDKI, 2017).

Hal ini juga diungkapkan oleh penelitian Ungsianik \& Yuliati (2017) menemukan bahwa terdapat sebanyak 47\% remaja melakukan masturbasi. Hasil survey tersebut juga ditemukan data alasan remaja melakukan hubungan seks sebelum menikah diantaranya yaitu 57,5\% remaja lakilaki merasa penasaran atau ingin tahu, $38 \%$ remaja perempuan terjadi begitu saja dan $12,6 \%$ perempuan karena dipaksa oleh pasangan. Oleh karena itu dapat diasumsikan bahwa remaja saat ini rentan terjadi perubahan status kesehatan akibat dampak dari perilaku seksual berisiko.

Dampak perilaku seksual berisiko sangat erat kaitannya dengan infeksi menular seksual. Control Disease Centre (CDC) melaporkan hasil survey beberapa negara di dunia terdapat remaja yang menderita 
infeksi menular seksual seperti Chlamydia dan Gonorrhea. Secara berturut-turut dari kedua kasus tersebut mengalami peningkatan yang signifikan dari tahun 2014-2017 yaitu sebesar 4,0\% dan 5,8\%. Di kawasan benua Amerika, ditemukan penderita Chlamydia dengan jumah tiga kali lipat lebih banyak pada remaja putri dibandingkan laki-laki dan usia dominan yaitu 15-24 tahun. Sementara itu, di kawasan Asia infeksi menular seksual lebih banyak ditemukan di Asia Selatan dan Asia Tenggara dengan jumlah kasus sebanyak 50 juta kasus per tahunnya dan salah satu penyumbang angka terbesar di Asia Tenggara adalah di negara Indonesia (CDC, 2016). Di Indonesia, pada bulan Maret-April 2017 dilaporkan bahwa ditemukannya kasus Duh Tubuh Uretra (DTU) atau biasa dikenal dengan kencing nanah sebanyak 2.229 kasus dan ulkus genital sebanyak 363 kasus. Kasus tersebut lebih banyak ditemukan pada usia remaja sampai dewasa (Dirjen PP\&PL Kemenkes RI Triwulan I, 2017).

Salah satu faktor yang berperan penting dalam proses perkembangan remaja adalah faktor intelegensi. Cerdas secara intelegensi pada remaja seperti yang diungkapkan oleh Mokrysz et al., (2016) adalah bagaimana remaja tersebut memiliki kemampuan dalam mendapatkan dan mengaplikasikan pengetahuan sehingga tidak dapat dipisahkan dari kognisi. Hasil survey yang dilakukan kepada 6800 remaja berusia 12-25 tahun yang berada di wilayah berkembang yaitu Thailand terkait dengan intelegensinya dilaporkan bahwa 39\% remaja memiliki cerdas intelegensi tinggi, 37\% memiliki cerdas intelegensi rata-rata dan lainnya memiliki cerdas intelegensi rendah (Noipayak et al., 2016).

Status intelegensi yang masih terbilang rendah pada remaja, dapat menyebabkan masalah kesehatan khususnya perilaku menyimpang pada remaja. Hal ini senada dengan penelitian Simak, Fitriyani, \& Setiawan (2018) yang menjelaskan bahwa kecerdasan intelegensi pada usia remaja dapat memperkuat keputusan seksual seperti menunda untuk melakukan hubungan seksual pertama. 
Penelitian lain menjelaskan hal yang sama dilakukan pada anak SMA terkait dengan hubungan kecerdasan intelegensi dan kecenderungan perilaku seks pra nikah yang hasilnya adalah semakin meningkatnya kecerdasan intelegensi maka kecenderungan perilaku seks pranikah pada anak remaja akan semakin rendah (Apsari \& Purnamasari, 2017). Penelitian ini berfokus pada Intelegensi Quotient (IQ) pada remaja usia 17-19 tahun dibandingkan penelitian sebelumnya menggunakan responden pada anak SMA. Berdasarkan hal tersebut maka diasumsikan bahwa masih perlu adanya perhatian secara khusus berkaitan dengan kecerdasan intelegensi remaja sehingga mereka menyadari bahwa ketika remaja berada diluar kontrol orang tua terhindar dari perilaku seksual berisiko.

\section{METODE}

Penelitian ini menggunakan analitik kuantitatif dengan desain cross sectional. Penelitian analitik adalah untuk mencari hubungan antar variabel yang akan diteliti (Dharma, 2011). Desain cross sectional adalah penelitian yang mengamati korelasi antara independen terhadap dependen, berdasarkan pendekatan atau pengumpulan data yang dilaksanakan secara bersama-sama pada waktu yang sama (Masturoh \& Anggita, 2018). Penelitian ini dilakukan di perguruan tinggi swasta di Jakarta. Sampel pada penelitian ini adalah mahasiswa berusia 17-19 tahun, dengan menggunakan teknik purposive sampling.

Instrumen penelitian yang digunakan adalah kuesioner dan hasil tes IQ oleh TRUST Psikologi Jakarta. Hasil tes IQ digunakan untuk mengetahui nilai IQ mahasiswa saat tes ujian masuk perguruan tinggi. Pengukuran perilaku seksual berisiko diukur menggunakan kuesioner Sexual Risk Survey (SRS) dengan jumlah 23 pertanyaan (Turchik \& Garske, 2009). Lebih lanjut, kuesioner ini sudah diterjemahkan dan dimodifikasi oleh 3 peneliti sebelumnya yaitu Nurhayati (2011), Nurmaguphita (2014) dan Simak et al., (2018) dengan hanya menggunakan 19 pertanyaan yang sudah disesuaikan dengan kondisi remaja di Indonesia. 
Dalam proses penelitian ini menggunakan pertimbangan etik. Pertimbangan etik digunakan untuk mencegah munculnya masalah etik selama penelitian berlangsung, untuk itu peneliti berupaya untuk mengantisipasi dan mengatasi masalah yang muncul. Terdapat 3 (tiga) prinsip etik umum yang diterapkan untuk mengatasi masalah etik yaitu non maleficence dan beneficence, respect to person, serta justice (Polit \& Beck, 2012).

\section{HASIL DAN PEMBAHASAN}

Hasil penelitian terdiri dari identifikasi karakteristik responden, hasil uji analisis bivariat dan multivariat.

Tabel 1 menunjukkan bahwa mayoritas umur mahasiswa adalah 19 tahun dengan persentase sebesar 48,3\%. Jenis kelamin mahasiswa sebagian besar adalah perempuan dengan persentase sebesar 91,8\%. Pendidikan orang tua mayoritas menunjukkan tamat SMA dengan persentase sebesar 59,9\%.
Tabel 1

Distribusi Karakteristik Remaja di Jakarta Pusat, Desember 2019 ( $n=147)$

\begin{tabular}{|c|c|c|}
\hline Karakteristik & Frekuensi (n) & Persentase $(\%)$ \\
\hline \multicolumn{3}{|l|}{ Umur } \\
\hline 17 tahun & 7 & 4,8 \\
\hline 18 tahun & 69 & 46,9 \\
\hline 19 tahun & 71 & 48,3 \\
\hline \multicolumn{3}{|l|}{ Jenis Kelamin } \\
\hline Laki-laki & 12 & 8,2 \\
\hline Perempuan & 135 & 91,8 \\
\hline \multicolumn{3}{|l|}{ Pendidikan Orang } \\
\hline \multicolumn{3}{|l|}{ Tua } \\
\hline $\mathrm{SD}$ & 23 & 15,6 \\
\hline SMP & 20 & 13,6 \\
\hline SMA & 88 & 59,9 \\
\hline $\mathrm{D} 3 / \mathrm{S} 1 / \mathrm{S} 2 / \mathrm{S} 3$ & 16 & 10,9 \\
\hline \multicolumn{3}{|l|}{ Pendapatan Orang } \\
\hline \multicolumn{3}{|l|}{ Tua } \\
\hline$<=$ Rp. 3.940 .973 & 86 & 58,5 \\
\hline$>$ Rp. 3.940.973 & 61 & 41,5 \\
\hline \multicolumn{3}{|l|}{ Sumber Informasi } \\
\hline Teman Sebaya & 46 & 31,3 \\
\hline Internet & 99 & 67,4 \\
\hline Lain-lain & 2 & 1,4 \\
\hline \multicolumn{2}{|l|}{ Perilaku Seksual } & Berisiko \\
\hline Tidak Berisiko & 75 & 51 \\
\hline Berisiko & 72 & 49 \\
\hline \multicolumn{3}{|l|}{ Kecerdasan } \\
\hline \multicolumn{3}{|l|}{ Intelektual } \\
\hline Sedang & 29 & 19,7 \\
\hline Cukup & 117 & 79,6 \\
\hline Tinggi & 1 & 0,7 \\
\hline
\end{tabular}

Pendapatan orang tua menunjukkan bahwa sebagian besar $<=$ Rp. 3.940.973 dengan persentase sebesar $58,5 \%$. Sumber informasi sebagian besar dari internet dengan persentase sebesar 67,4\%. Sebagian besar mahasiswa memiliki perilaku seksual tidak berisiko dengan persentase sebesar 51\%. Mayoritas kecerdasan intelektual mahasiswa cukup atau rata-rata dengan persentase sebesar $79,6 \%$. 
Tabel 2

Hubungan antara Intelligence Quotient (IQ) dengan perilaku seksual berisiko pada Remaja di Jakarta Pusat, Desember $2019(n=147)$

\begin{tabular}{lcccccc}
\hline \multirow{2}{*}{ Variabel } & \multicolumn{7}{c}{ Tidak Berisiko } & \multicolumn{2}{c}{ Perilaku Seksual Berisiko } & \multirow{2}{*}{ OR $(95 \% \mathrm{CI})$} & $\mathrm{p}$ value \\
& $\mathrm{n}$ & $\%$ & $\mathrm{n}$ & $\%$ & & \\
\hline $\begin{array}{l}\text { Intelligence } \\
\text { Quotient }\end{array}$ & & & & & & \\
Sedang & 61 & 91 & 6 & 9 & & \\
Cukup & 13 & 16,5 & 66 & 83,5 & $22(0,561-0,801)$ & 0,000 \\
Tinggi & 1 & 100 & 0 & 0 & & \\
\hline
\end{tabular}

Tabel 2 hasil analisis bivariat menunjukkan adanya hubungan yang signifikan antara Intelligence Quotient (IQ) dengan perilaku seksual berisiko ( $\mathrm{p}$ value $=0,000)$. Mahasiswa dengan Intelligence Quotient (IQ) tinggi berpeluang 22

kali untuk memiliki perilaku seksual tidak berisiko dibandingkan mahasiswa dengan Intelligence Quotient (IQ) sedang (OR=22; 95\% CI 0,561-0,801). Hal ini menunjukkan bahwa semakin tinggi Intelligence Quotient (IQ) maka perilaku seksual semakin tidak berisiko.

Tabel 3

Hubungan antara Usia, Jenis Kelamin, Pendidikan Orang Tua, Pendapatan Orang Tua dan Sumber Informasi dengan Perilaku Seksual Berisiko pada Remaja di Jakarta Pusat, Desember 2019 $(n=147)$

\begin{tabular}{|c|c|c|c|c|c|}
\hline \multirow{3}{*}{ Var. Independen } & \multicolumn{4}{|c|}{ Var. Dependen Perilaku Seksual Berisiko } & \multirow{3}{*}{$P$ value } \\
\hline & \multicolumn{2}{|c|}{ Tidak Berisiko } & \multicolumn{2}{|c|}{ Berisiko } & \\
\hline & $\mathrm{n}$ & $\%$ & $\mathrm{n}$ & $\%$ & \\
\hline \multicolumn{6}{|l|}{ Umur } \\
\hline 17 tahun & 2 & 28,6 & 5 & 71,4 & \multirow{3}{*}{0,377} \\
\hline 18 tahun & 38 & 55,1 & 31 & 44,9 & \\
\hline 19 tahun & 35 & 49,3 & 36 & 50,7 & \\
\hline \multicolumn{6}{|l|}{ Jenis Kelamin } \\
\hline Laki-laki & 5 & 41,7 & 7 & 58,3 & \multirow[t]{2}{*}{0,499} \\
\hline Perempuan & 70 & 51,9 & 65 & 48,1 & \\
\hline \multicolumn{6}{|l|}{ Pendidikan Ortu } \\
\hline SD & 13 & 56,5 & 10 & 43,5 & \multirow{4}{*}{0,902} \\
\hline SMP & 11 & 55,0 & 9 & 45,0 & \\
\hline SMA & 43 & 48,9 & 45 & 51,1 & \\
\hline $\mathrm{D} 3 / \mathrm{S} 1 / \mathrm{S} 2 / \mathrm{S} 3$ & 8 & 50,0 & 8 & 50,0 & \\
\hline \multicolumn{6}{|l|}{ Pendapatan Ortu } \\
\hline$<=$ Rp. 3.940.973 & 44 & 51,2 & 42 & 48,8 & \multirow[t]{2}{*}{0,967} \\
\hline$>$ Rp. 3.940.973 & 31 & 50,8 & 30 & 49,2 & \\
\hline \multicolumn{6}{|l|}{ Sumber Informasi } \\
\hline Teman Sebaya & 18 & 39,1 & 28 & 60,9 & \multirow{3}{*}{0,125} \\
\hline Internet & 55 & 52,2 & 44 & 47,8 & \\
\hline Lain-lain & 2 & 100,0 & 0 & 0,0 & \\
\hline
\end{tabular}


Pada tabel 3. berdasarkan hasil uji bivariat dapat dilihat bahwa tidak ada hubungan yang signifikan antara umur mahasiswa, jenis kelamin, pendidikan orang tua, pendapatan orang tua dan sumber informasi dengan perilaku seksual berisiko ( $\mathrm{p}$ value $=0,377 ; 0,499 ; 0,902 ; 0,967$; $0,125)$.

Tabel 4

Model Seleksi Multivariat Variabel yang Berhubungan dengan Perilaku Seksual Berisiko pada Remaja di STIKes RS Husada Jakarta Pusat $(n=147)$

\begin{tabular}{lccccc}
\hline & & & \multicolumn{2}{c}{$95,0 \%$} \\
Model & & & \multicolumn{3}{c}{$\begin{array}{c}\text { Confidence } \\
\end{array}$} \\
& & Sig. & \multicolumn{2}{c}{ Interval for B } \\
\cline { 3 - 6 } & & & Lower & Upper \\
& & & Bound & Bound \\
\hline Constant) & 1,246 &, 215 &,- 225 &, 991 \\
Umur &,- 405 &, 686 &,- 124 &, 082 \\
Jenis Kelamin &, 409 &, 683 &,- 176 &, 267 \\
Pendidikan Orang tua &, 434 &, 665 &,- 054 &, 084 \\
Pendapatan Orang & & & & \\
Tua &, 206 &, 837 &,- 109 &, 134 \\
Sumber Informasi &,- 592 &, 555 &,- 093 &, 050 \\
Intelligence Quotient & 11,239 &, 000 &, 561 &, 801 \\
\hline
\end{tabular}

Berdasarkan tabel 4. menunjukkan hasil uji logistic tahap satu yang dimasukkan variabel umur, jenis kelamin, pendidikan orang tua, pendapatan orang tua, sumber informasi dan Intelligence Quotient (IQ). Berdasarkan analisis multivariat yang telah dilakukan, dapat disimpulkan bahwa variabel dominan yang paling memengaruhi perilaku seksual berisiko pada mahasiswa adalah Intelligence quotient dengan nilai $p$ value $=0,000(\alpha<0,05)$.

Hasil penelitian ini menunjukkan bahwa ada hubungan yang signifikan antara Intelligence Quotient (IQ) dengan perilaku seksual berisiko pada mahasiswa. Mahasiswa dengan Intelligence Quotient (IQ) tinggi berpeluang 22 kali untuk memiliki perilaku seksual tidak berisiko dibandingkan mahasiswa dengan Intelligence Quotient (IQ) sedang. Semakin tinggi Intelligence Question (IQ) maka perilaku seksual semakin tidak berisiko. Mahasiswa memiliki kecenderungan bersifat high curiosity atau memiliki rasa ingin tahu yang tinggi terhadap hal-hal yang berhubungan dengan seksualitas.

Seorang mahasiswa yang memiliki Intelligence Quotient (IQ) tinggi cenderung mempertimbangkan konsekuensi negative dari perilaku seksual berisiko daripada mahasiswa yang memiliki Intelligence Quotient (IQ) sedang atau cukup. Hal ini menunjukkan bahwa perilaku seksual berisiko mengacu pada segala sesuatu 
yang berkaitan dengan perkembangan kepribadian maupun kecerdasan intelektual.

Hasil penelitian ini sejalan dengan penelitian yang dilakukan oleh Kahn \& Halpern (2018) di United States yang melakukan penelitian mengenai hubungan antara kemampuan intelektual dengan perilaku seksualitas pada remaja. Hubungan yang lebih berfokus pada perilaku seksualitas ini menunjukkan bahwa ada hubungan yang signifikan antara kemampuan intelektual dengan perilaku seksualitas pada remaja. Hasil yang sama pula didapatkan pada penelitian yang dilakukan oleh Macapagal et al (2011) mengenai hubungan antara kecerdasan kognitif dengan dorongan seksualitas pada remaja. Berdasarkan penelitian ini menunjukkan hasil bahwa remaja yang memiliki kecerdasan kognitif di atas rata-rata memiliki dorongan seksualitas rendah daripada remaja dengan kecerdasan rata-rata atau dibawah rata-rata.

Penelitian lain yang dapat memperkuat hasil penelitian ini diantaranya penelitian yang dilakukan oleh Baines et al (2018) di
England mengenai hubungan antara perilaku seksual dengan ketidakmampuan intelektual pada remaja. Responden pada penelitian ini adalah remaja yang memiliki Intelligence Quotient (IQ) < 70 atau di bawah rata-rata. Hasil penelitian ini menunjukkan bahwa semakin rendah Intelligence Quotient (IQ) maka semakin tinggi perilaku seksual pada remaja.

Semakin tingginya angka hubungan seksual pranikah diikuti dengan semakin tingginya pula dampak dari hubungan seksual pranikah tersebut. Tidak hanya dapat menimbulkan gangguan secara fisik, perilaku seksual berisiko juga dapat memengaruhi kondisi mental seseorang (Epstein et al., 2014).

Remaja yang memiliki perilaku seksual berisiko diketahui mengalami peningkatan dari waktu ke waktu. Rendahnya pengetahuan tentang kesehatan reproduksi dan kontrol dari orangtua dapat membuat remaja berperilaku seksual berisiko. Ada dua hal penting yang mendasari perilaku seksual pada remaja yaitu harapan untuk menikah dalam usia yang relatif kecil (umur 20 tahun) dan 
semakin derasnya arus informasi yang dapat menimbulkan rangsangan seksual pada remaja, terutama remaja di daerah perkotaan.

Masa remaja merupakan masa perkembangan psikoseksual dimana pada tahap ini perubahan yang sangat menonjol adalah ketika terjadi kematangan fungsi seksual yang ditampilkan melalui perubahan perilaku. Perilaku seksual berisiko merupakan perilaku seksual yang dapat menyebabkan dampak negatif seperti kehamilan yang tidak diinginkan, aborsi, dan penyakit menular seksual (Kahn \& Halpern, 2018). Oleh karena itu diperlukan sebuah kendali yang mampu mengarahkan perilaku seksual remaja supaya jauh dari hal-hal yang bersifat negatif dan membahayakan kesehatan mereka (Macapagal et al., 2011). Salah satu upaya yang bisa dioptimalkan untuk mencegah remaja memiliki perilaku seksual berisiko ialah dengan mengembangkan kognitif atau kecerdasan intelektual (Mokrysz et al., 2016).

Usia remaja merupakan masa transisi dari anak-anak menuju masa dewasa awal yang masih mempunyai tanggung jawab untuk menyelesaikan tugas perkembangannya. Tugas perkembangan remaja terfokus dari masa kanak-kanak dan persiapan menjadi dewasa, termasuk perilaku seksual berisiko. Remaja melakukan hubungan seksual berisiko mungkin disebabkan oleh adanya dorongan dari diri sendiri untuk melakukan hubungan seksual, pengalaman yang dilalui mengenai seksual yang mengakibatkan mereka untuk mengulanginya kembali, faktor emosional yang masih labil, dan kurangnya informasi yang benar tentang kesehatan reproduksi terutama yang berhubungan dengan seksual (Simak et al., 2018).

Kecerdasan erat kaitannya dengan kemampuan kognitif yang dimiliki oleh individu (Wraw et al., 2018). Menurut Noipayak et al (2016) kecerdasan dapat diukur dengan menggunakan alat psikometri yang biasa disebut sebagai tes IQ. Ada juga pendapat yang menyatakan bahwa IQ merupakan usia mental yang dimiliki manusia berdasarkan perbandingan usia kronologis.

Intelligence Quotient (IQ) atau skor kecerdasan bisa naik dan turun. 
Perubahan IQ itu terkait dengan perubahan struktur otak pada remaja. IQ memiliki hubungan negatif dengan perilaku seksual berisiko pada remaja. Remaja dengan IQ tinggi berupaya meningkatkan kemampuan kognitif untuk mengembangkan diri daripada melakukan perilaku seksual berisiko yang dapat berdampak buruk di masa depannya. Kecerdasan pada masa anak-anak dan remaja sangat berkaitan dengan kinerja yang baik di masa dewasa. Salah satu kinerja yang baik ditunjukkan dengan tidak memiliki perilaku seksual berisiko (Makharia et al., 2016).

Hormon seksual sudah mulai berfungsi pada masa remaja. Hal tersebut mendorong remaja untuk melakukan berbagai jenis perilaku seksual. Selain itu, faktor modernisasi membuat gaya hidup remaja saat ini telah berubah. Akibatnya, remaja cenderung tidak terjaga oleh sistem keluarga dan nilai posistif adat budaya, sehingga lebih toleransi terhadap gaya hidup seksual pranikah, perubahan orientasi seksual, dan jumlah pasangan (Sawyer et al., 2018).

Intelligence Quotient (IQ) yang tinggi pada mahasiswa mencerminkan sikap penuh rasa percaya diri mengenai apa yang berlaku atau apa yang benar bagi dirinya. Kepercayaan datang dari apa yang dilihat atau apa yang diketahui. Berdasarkan apa yang telah dilihat itu kemudian terbentuk suatu ide atau gagasan mengenai sifat atau karakteristik umum suatu objek. Sekali kepercayaan itu telah terbentuk, maka ia akan menjadi dasar pengetahuan seseorang mengenai apa yang dapat diharapkan dari objek tertentu. Penelitian Checa \& Fernández-Berrocal (2015) menyebutkan bahwa remaja dengan IQ tinggi memiliki pengetahuan yang baik dan tertarik dengan hal-hal yang dapat mengembangkan kreativitas remaja. Remaja dengan IQ tinggi lebih berfokus pada konsekuensi baik dan buruk terhadap dirinya ke depan sehingga remaja dengan IQ tinggi tidak mengambil risiko yang dapat berdampak buruk bagi dirinya. Kahn \& Halpern (2018) menyatakan bahwa remaja dengan IQ tinggi memiliki kontrol diri yang baik dan mampu mengendalikan keinginan untuk menghindari perilaku seksual berisiko. Mahasiswa yang memiliki kecerdasan kognitif dibawah rata-rata 
cenderung bersifat aktif dalam pola interaksi romantik dengan lawan jenis dan mudah terangsang sehingga berpeluang besar untuk memiliki perilaku seksual yang tinggi.

Perilaku seksual berisiko merupakan kegiatan seksual yang akan meningkatkan peluang seseorang yang melakukannya terkena atau menularkan penyakit menular seksual (PMS) atau menyebabkan kehamilan. Semakin tingginya angka hubungan seksual pranikah diikuti dengan semakin tingginya pula dampak dari hubungan seksual pranikah tersebut. Tidak hanya dapat menimbulkan gangguan secara fisik, perilaku seksual berisiko juga dapat memengaruhi kondisi mental seseorang (Epstein et al., 2014).

Remaja yang memiliki perilaku seksual berisiko diketahui mengalami peningkatan dari waktu ke waktu. Rendahnya pengetahuan tentang kesehatan reproduksi dan kontrol dari orangtua dapat membuat remaja berperilaku seksual berisiko. Ada dua hal penting yang mendasari perilaku seksual pada remaja yaitu harapan untuk menikah dalam usia yang relatif kecil (umur 20 tahun) dan semakin derasnya arus informasi yang dapat menimbulkan rangsangan seksual pada remaja, terutama remaja di daerah perkotaan.

Intelligence Quotient (IQ) yang tinggi akan terlihat dari kemampuan mahasiswa menyerap segala macam informasi kemudian mengolah dan menganalisa untuk menentukan mana yang baik dan buruk. Sementara itu mahasiswa dengan IQ di bawah ratarata mudah mengikuti arus informasi yang semakin mudah diakses tanpa mengolah atau menganalisisnya sehingga cenderung memiliki keinginan untuk mencoba hal-hal baru termasuk perilaku seksual berisiko. Hal ini tentu menjadi perhatian lebih bagi para orang tua untuk lebih memperhatikan dan mengawasi pergaulan dari para mahasiswa agar terhindar dari dampak perilaku seksual berisiko.

Banyak mahasiswa mungkin merasa dianggap kurang pergaulan jika tidak mengikuti gaya hidup yang biasa dilakukan di usia remaja seperti berpacaran. Mayoritas mahasiswa yang berpacaran sangat memperhatikan penampilan supaya lawan jenis semakin tertarik. Hal ini 
menyebabkan mahasiswa yang berpacaran lebih berfokus menjaga hubungan baiknya dengan lawan jenis tanpa mementingkan perilaku yang dilakukan selama berpacaran misalnya perilaku seksual berisiko (Ungsianik \& Yuliati, 2017). Konsisten dengan teori psikologi oleh Djamarah (2011) bahwa seorang remaja dapat mengembangkan kebutuhan psikologi melalui pergaulan atau sosialisasi dengan teman sebaya. Peranan teman-teman sebaya terhadap remaja terutama berkaitan dengan sikap, pembicaraan, minat, penampilan dan perilaku. Remaja sering kali menilai bahwa bila dirinya memakai model pakaian yang sama dengan anggota kelompok yang populer, maka kesempatan baginya untuk diterima oleh temanteman sebayanya menjadi besar. Demikian pula bila anggota kelompok mencoba minum alkohol, obat-obatan terlarang atau perilaku seksual berisiko, maka remaja cenderung mengikutinya tanpa memperdulikan perasaannya sendiri dan akibatnya.

Perilaku mahasiswa mengacu pada sistem peran. Peran seorang mahasiswa yang sedang dalam proses pencarian jati diri memiliki kecenderungan untuk mengadopsi sikap dan perilaku lingkungan sekitarnya. Gaya hidup mahasiswa semakin hari semakin mengkhawatirkan diiringi dengan perkembangan teknologi dan informasi yang bisa diakses dengan mudah. Hal ini akan menyebabkan perilaku menyimpang salah satunya adalah perilaku seksual berisiko. Pergeseran budaya menyebabkan mahasiswa tidak canggung lagi menunjukkan perilaku seksual berisiko bahkan di depan umum atau khalayak ramai misal dengan berpegangan tangan, berciuman kening, berciuman bibir, meraba atau berpelukan. Oleh karena itu, faktor kecerdasan intelektual dapat menjadi salah satu tolak ukur terjadinya perilaku seksual berisiko di kalangan remaja (Checa \& FernándezBerrocal, 2015).

Pada penelitian ini sebagian besar mahasiswa menunjukkan adanya hubungan yang signifikan antara intelligence quotient (IQ) dengan perilaku seksual berisiko. Perilaku seksual berisiko pada mahasiswa dipengaruhi oleh faktor eksternal maupun internal. Salah satu faktor 
internal mahasiswa yang memengaruhi perilaku seksual tidak memerlukan banyak pemikiran, berisiko adalah intelligence quotient (IQ) (Baines et al., 2018). Hal ini sejalan dengan teori perilaku oleh Lawrence dalam Terzian, Andrews \& Moore (2011) yang menyatakan bahwa intelligence quotient (IQ) merupakan faktor yang berkontribusi dalam pembentukan teori sistem perilaku manusia.

Perilaku seksual berisiko remaja berdasarkan teori perilaku oleh Lawrence adalah suatu proses interaksi antara faktor perilaku dan faktor diluar perilaku yang saling berhubungan untuk menghasilkan suatu output yaitu perilaku. Perilaku yang dibentuk akan mendorong individu untuk melakukan suatu hal karena mereka berpikir tindakan yang akan dilakukan terarah pada perilaku yang dibentuk. Remaja yang masih dalam tahap pembentukan identitas dan pencarian jati diri harus menghadapi kehidupan sosialnya yang aktif dan dinamis sehingga pergaulan remaja sangat dekat dengan perilaku seksual berisiko (Kipping et al., 2014). Remaja yang memiliki IQ rendah atau di bawah rata-rata cenderung menggunakan kemampuan berbeda dengan remaja dengan IQ tinggi lebih banyak menghabiskan waktu untuk berpikir (Checa \& Fernández-Berrocal, 2015). Hal ini menyebabkan remaja dengan IQ rendah atau di bawah rata-rata cenderung memiliki perilaku seksual berisiko daripada remaja dengan IQ tinggi (Wraw et al., 2018).

Intelligence quotient (IQ) pada mahasiswa menjadi salah satu penanda dalam menganalisa perilaku seksual berisiko. Ada dua hal penting yang mendasari perilaku seksual berisiko pada mahasiswa yaitu harapan untuk menikah dalam usia yang relative muda $(<20$ tahun) dan semakin derasnya arus informasi yang dapat menimbulkan rangsangan seksual pada remaja, terutama remaja di daerah perkotaan. Rangsangan tersebut mendorong remaja untuk melakukan hubungan seksual pra nikah (Macapagal et al., 2011). Oleh karena itu peran orang tua sangat penting dalam mendidik, memberikan contoh yang baik, mendampingi, mengawasi dan sebagai konselor bagi remaja agar terhindar dari perilaku seksual berisiko yang dapat 
berdampak buruk pada kesehatannya (Ungsianik \& Yuliati, 2017).

Perilaku seksual berisiko pada mahasiswa sangat beragam antara lain meraba atau merangsang pasangannya, berciuman bibir, berpegangan tangan, berpelukan hingga berhubungan seksual. Hasil penelitian ini menunjukkan bahwa mayoritas mahasiswa memiliki perilaku seksual tidak berisiko. Hal ini dipengaruhi oleh berbagai faktor salah satunya adalah mahasiswa yang menuntut ilmu di perguruan tinggi swasta cenderung fokus untuk mengembangkan kemampuan kognitif, afektif dan psikomotor selama menempuh studi di kampus daripada mencoba hal-hal yang diyakini dapat berpengaruh buruk pada kehidupannya seperti perilaku seksual berisiko. Hal ini sejalan dengan penelitian yang dilakukan oleh Goldenberg et al (2019) di United States pada kelompok remaja yang berperilaku seksual menyimpang yaitu gay memiliki tingkat kecerdasan kognitif yang rendah. Remaja yang memiliki IQ tinggi maupun rendah berpotensi memiliki perilaku seksual berisiko dikarenakan faktor lingkungan sangat berpengaruh kuat pada pergaulan remaja.

Mahasiswa yang memiliki pengalaman sebelumnya tentang pola romantik atau gaya berpacaran tentu saja telah mengetahui gambaran berpacaran dengan lawan jenisnya (Umaroh, Kusumawati \& Kasjono, 2015). Berpacaran merupakan masa pendekatan antar individu dari kedua lawan jenis, yang ditandai dengan saling pengenalan pribadi baik kekurangan dan kelebihan dari masing-masing individu. Dalam hal ini berpacaran mempunyai dua jenis yaitu pacaran sehat dan pacaran tidak sehat. Pacaran sehat meliputi pacaran sehat secara fisik, psikis, dan sosial. Sementara itu, pacaran tidak sehat meliputi kissing, necking, petting dan intercourse. Mahasiswa pada umumnya mengharapkan hubungan dengan lawan jenisnya dapat selalu langgeng hingga ke jenjang pernikahan sehingga gaya berpacaran mereka dapat dikatakan kebablasan. Hasil penelitian ini menunjukkan bahwa ada hubungan yang signifikan antara IQ dengan perilaku seksual berisiko. Hal ini sejalan dengan penelitian yang dilakukan oleh Terzian et al (2011) menunjukkan 
bahwa IQ rendah merupakan salah satu faktor yang memengaruhi perilaku seksual berisiko pada remaja. IQ rendah merupakan salah satu faktor individu yang sulit untuk diubah sehingga banyak studi menunjukkan bahwa IQ rendah rentan memiliki perilaku seksual berisiko.

Penelitian lain yang dilakukan oleh Nursal (2008) menyebutkan faktorfaktor yang memengaruhi perilaku seksual berisiko adalah usia, jenis kelamin, pendidikan orang tua, pendapatan orang tua dan sumber informasi. Perilaku seksual berisiko pada remaja dipengaruhi oleh faktor internal maupun eksternal remaja. Faktor internal dari remaja yang memengaruhi perilaku seksual berisiko ialah usia, jenis kelamin, tingkat pendidikan, pengetahuan, sikap dan gaya hidup (Ungsianik \& Yuliati, 2017). Faktor-faktor seperti pendapatan keluarga, status social ekonomi dan sumber informasi akan memengaruhi perilaku seksual berisiko (Sitohang et al., 2018). Hal ini berkaitan dengan pola perilaku remaja dalam menghadapi perubahan baik secara fisik, psikologis maupun emosional.
Mahasiswa laki-laki cenderung lebih dominan daripada mahasiswi perempuan. Jenis kelamin mahasiswa tidak menunjukkan adanya hubungan dengan perilaku seksual berisiko. Hal ini bertolak belakang dengan penelitian yang dilakukan oleh Mahmudah et al (2016) bahwa jenis kelamin memengaruhi perilaku seksual berisiko pada remaja. Ada norma yang lebih longgar bagi lakilaki dibanding perempuan, akibatnya laki-laki berpeluang lebih besar melakukan berbagai hal dibandingkan perempuan. Laki-laki cenderung lebih bebas dibandingkan perempuan (Apsari \& Purnamasari, 2017). Orang tua lebih protektif pada remaja perempuan daripada laki-laki sehingga dapat dipahami jika laki-laki memiliki peluang lebih besar untuk berperilaku seksual berisiko dibanding perempuan. Namun seiring dengan berkembangnya teknologi serta kemudahan remaja mengakses berbagai informasi maka remaja lakilaki maupun perempuan sama-sama memiliki perilaku seksual berisiko.

Pendidikan orang tua pada mahasiswa sebagian besar memiliki tingkat pendidikan yang tinggi. Status pendidikan yang tinggi tidak 
menunjukkan adanya hubungan dengan perilaku seksual berisiko. Hal ini bertolak belakang dengan penelitian Simak et al (2018) bahwa tingkat pendidikan orang tua dapat memengaruhi perilaku seksual berisiko pada remaja. Pendidikan yang tinggi dapat mengendalikan atau mengontrol diri-sendiri dalam pola perilaku yang berkembang di masyarakat salah satunya perilaku seksual berisiko (Terzian et al., 2011). Tingkat pendidikan yang tinggi mampu menyerap berbagai macam informasi dengan baik serta mampu mengolah dan menganalisis untuk diyakini sebagai hal yang baik atau benar. Perilaku seksual berisiko pada remaja tidak dipengaruhi oleh pendidikan orang tua dikarenakan faktor lingkungan yang membentuk pergaulan remaja.

Pendapatan orang tua tidak memengaruhi perilaku seksual berisiko pada mahasiswa. Pendapatan orang tua yang rendah tidak memengaruhi perilaku seksual berisiko pada remaja. Remaja dengan pendapatan orang tua yang tinggi maupun rendah sama-sama memiliki perilaku seksual tidak berisiko atau tidak berbeda perilaku seksualnya.
Jadi pendapatan orang tua bukan merupakan faktor yang ada hubungannya dengan perilaku seksual berisiko pada remaja. Hal ini bertolak belakang dengan penelitian yang dilakukan oleh Umaroh et al (2015) yang menunjukkan bahwa pendapatan orang tua memengaruhi perilaku seksual berisiko pada remaja. Remaja dengan pendapatan orang tua yang tinggi memungkinkan mendapatkan lebih banyak uang saku untuk kesehariannya. Hal ini menyebabkan peluang bagi remaja menggunakan uang sakunya tidak hanya untuk kebutuhan pokok tetapi juga dapat digunakan untuk kepentingan yang lain misalnya pergi bersama pacar dan lain-lain. Namun saat ini seiring adanya pregeseran budaya menyebabkan remaja lakilaki maupun perempuan cenderung berperilaku seksual berisiko secara terbuka di depan umum tanpa mengeluarkan uang.

Sumber informasi remaja dalam halhal yang terkait dengan reproduksi atau seksual sebagian besar dari internet. Hasil penelitian ini menunjukkan bahwa tidak ada hubungan yang signifikan antara sumber informasi dengan perilaku 
seksual remaja. Hal ini bertolak belakang dengan penelitian yang dilakukan oleh Hasanah et al (2020) yang menunjukkan bahwa ada hubungan antara sumber informasi dengan perilaku seksual berisiko. Terbukanya akses informasi tentang seks bebas di masyarakat merupakan faktor penyebab, karena remaja selalu punya keinginan lebih untuk mencari informasi mengenai seks. Sumber informasi yang mereka akses diperoleh melalui internet, yang berpengaruh terhadap pergaulan remaja dengan lawan jenis yang akhirnya menjerumuskan remaja pada perilaku seksual berisiko.

\section{KESIMPULAN DAN SARAN}

Penelitian ini menunjukkan bahwa terdapat hubungan antara intelligence quotient (IQ) dengan perilaku seksual berisiko pada remaja. Remaja dengan intelligence quotient (IQ) tinggi memiliki peluang 22 kali memiliki perilaku seksual tidak berisiko dibandingkan remaja dengan intelligence quotient (IQ) rendah. Selain itu, faktor lain seperti umur, jenis kelamin, pendidikan orang tua, pendapatan orang tua dan sumber informasi tidak memiliki hubungan yang signifikan dengan perilaku seksual berisiko pada remaja. Faktor paling dominan yang memengaruhi perilaku seksual berisiko adalah intelligence quotient (IQ).

Saran terhadap pelayanan keperawatan maternitas adalah pemberian promosi kesehatan bagi remaja yang memiliki IQ cukup dan sedang dengan menggunakan pendekatan kognitif yang berfokus pada peningkatan kesadaran diri remaja terkait dengan perilaku seksual berisiko. Sementara bagi remaja yang memiliki IQ rendah memerlukan perhatian khusus berupa pendampingan dan pengawasan dengan melibatkan orang tua dalam pergaulan remaja. Institusi pendidikan juga dapat berperan mengembangkan program edukasi kesehatan reproduksi yang kreatif dan inovatif terkait mata ajar keperawatan maternitas mengenai seksualitas yang komprehensif yang mencakup seluruh permasalahan remaja yang disesuaikan dengan tingkat pertumbuhan dan perkembangan remaja. Penelitian selanjutnya dapat meneliti terkait Intelligence Quotient (IQ) ditambahkan nilai budaya, sikap, teman sebaya dengan perilaku seksual berisiko pada remaja dan keluarga 
dengan menggunakan pendekatan dan metode berbeda yaitu penelitian kualitatif dengan desain fenomenologi ataupun etnografi.

\section{DAFTAR PUSTAKA}

Baines, S., Emerson, E., Robertson, J., \& Hatton, C. (2018). Sexual activity and sexual health among young adults with and without mild/ moderate intellectual disability. BMC Public Health, 18(667).

https://doi.org/10.1186/s12889018-5572-9

Checa, P., \& Fernández-Berrocal, P. (2015). The Role of Intelligence Quotient and Emotional Intelligence in Cognitive Control Processes. Front. Psychol, 6(1853). https://doi.org/10.3389/fpsyg.20 15.01853

Epstein, M., Bailey, J. A., Manhart, L. E., Hill, K. G., \& Hawkins, J. D. (2014). Sexual Risk Behavior in Young Adulthood: Broadening the Scope Beyond Early Sexual Initiation. J Sex Res, 51(7), 721730.

https://doi.org/10.1080/0022449 9.2013.849652.

Goldenberg, T., Stephenson, R., \& Bauermeister, J. (2019). Cognitive and Emotional Factors Associated with Sexual Risk-Taking Behaviors among Young Men who Have Sex with Men. Archives of Sexual Behavior, 48(4), 1127-1136. https://doi.org/10.1007/s10508018-1310-8
Hasanah, D. N., Utari, D. M., Chairunnisa, \& Purnamawati, D. (2020). Faktor Internal Dan Eksternal Yang Mempengaruhi Perilaku Seksual Pranikah Remaja Pria Di Indonesia (Analisis SDKI 2017). Muhammadiyah Public Health Journal, 1(1). https://jurnal.umj.ac.id/index.ph $\mathrm{p} / \mathrm{MPHJ} /$

Jaworska, N., \& MacQueen, G. (2015). Adolescence as a unique developmental period. $J$ Psychiatry Neurosci, 40(5). https://doi.org/10.1503/jpn.1502 68

Kahn, N. F., \& Halpern, C. T. (2018). "The Relationship Between Cognitive Ability and Experiences of Vaginal, Oral, and Anal Sex in the United States." J Sex Res, 55(1), 99105.

https://doi.org/10.1080/0022449 9.2016.1247149.

Kipping, R. R., Smith, M., Heron, J., Hickman, M., \& Campbell, R. (2014). Multiple risk behaviour in adolescence and socioeconomic status: findings from a UK birth cohort. European Journal of Public Health, 25(1), 44-49.

https://doi.org/10.1093/eurpub/c ku078

Macapagal, K., Janssen, E., Fridberg, D. J., Finn, P. R., \& Heiman, J. R. (2011). The Effects of Impulsivity, Sexual Arousability, and Abstract Intellectual Ability on Men's and Women's Go/No-Go Task Performance. Arch Sex Behav, 40(5), 995-1006. 
https://doi.org/10.1007/s10508010-9676-2

Mahmudah, Yaunin, Y., \& Lestari, Y. (2016). Faktor-Faktor yang Berhubungan dengan Perilaku Seksual Remaja di Kota Padang. Jurnal Kesehatan Andalas, 5(2). http://jurnal.fk.unand.ac.id

Makharia, A., Nagarajan, A., \& Singh, Y. (2016). Effect of environmental factors on intelligence quotient of children. Industrial Psychiatry Journal, 25(2), 189-194. https://doi.org/10.4103/ipj.ipj_5 2_16

Miller, K. S., Forehand, R., \& Kotchick, B. A. (2018). Adolescent Sexual Behavior in Two Ethnic Minority Samples: The Role of Family Variables. Journal of Marriage and Family, 61(1). https://doi.org/10.2307/353885

Mokrysz, C., Landy, R., Gage, S., Munafò, M., Roiser, J., \& Curran, H. (2016). Are IQ and educational outcomes in teenagers related to their cannabis use? A prospective cohort study. Journal of Psychopharmacology, 30(2), 159-168.

https://doi.org/10.1177/0269881 115622241

Noipayak, P., Rawdaree, P., Supawattanabodee, B., \& Manusirivitthaya, S. (2016). Age at menarche and performance intelligence quotients of adolescents in Bangkok, Thailand: a cross-sectional study. BMC Pediatrics, 16(87). https://doi.org/10.1186/s12887016-0624-8
Nurhapipa, Alhidayati, \& Ayunda, G. (2017). Faktor-Faktor Yang Berhubungan Dengan Perilaku Seksual. JOMIS (Journal Of Midwifery Science), 1(2). https://core.ac.uk/download/pdf/ 230774295.pdf

Nurhayati. (2011). Hubungan Pola Komunikasi dan Kekuatan Keluarga Terhadap Perilaku Seksual Beresiko Pada Remaja di Wilayah Desa Tridaya Sakti Kecamatan Tambun Selatan Kabupaten Bekasi. Jurnal Keperawatan Komunitas

Nurmaguphita, D., Hamid, A. Y. S., \& Mustikasari. (2016). Pola Asuh Berhubungan Dengan Perilaku Seksual Beresiko Pada Remaja Di Kecamatan Pundong Kabupaten Bantul, DIY. Jurnal Kesehatan "Samodra Ilmu," $7(1)$.

https://docplayer.info/71695900 -Pola-asuh-berhubungandengan-perilaku-seksualberesiko-pada-remaja-dikecamatan-pundong-kabupatenbantul-diy.html

Sawyer, S. M., Azzopardi, P. S., Wickremarathne, D., \& Patton, G. (2018). The age of adolescence. The Age of Adolescence, 2(3), 223-228. https://doi.org/10.1016/S23524642(18)30022-1

Simak, V. F., Fitriyani, P., \& Setiawan, A. (2018). The Relationships between Risky Sexual Practices and Spiritual Intelligence of Adolescents in Indonesia. Comprehensive Child and Adolescent Nursing, 42(1). https://doi.org/10.1080/2469419 3.2019.1578298 
Sitohang, Y. S., Shaluhiyah, Z., \&

Widagdo, L. (2018). Faktor-

Faktor Yang Berhubungan

Dengan Praktik Orang Tua

Dalam Menghadapi Perilaku

Seksual Pada Remaja

Tunagrahita Ringan Di SLB

Kota Semarang. JURNAL KESEHATAN MASYARAKAT, $6(5)$.

Terzian, M. A., Andrews, K. M., \& Moore, K. A. (2011). Preventing Multiple Risky Behaviors among Adolescents: Seven Strategies. Brief Research to Results Child Trends, 24. https://www.childtrends.org/wp

content/uploads/2011/09/Child_ Trends-

2011_10_01_RB_RiskyBehavio rs.pdf

Umaroh, A. K., Kusumawati, Y., \& Kasjono, H. S. (2015). Hubungan Antara Faktor Internal Dan Faktor Eksternal Dengan Perilaku Seksual Pranikah Remaja Di Indonesia. Jurnal Kesehatan Masyarakat Andalas, 10(1), 65-75. http://jurnal.fkm.unand.ac.id/ind ex.php/jkma/article/viewFile/16 $5 / 160$
Ungsianik, T., \& Yuliati, T. (2017).

Pola Asuh Orang Tua Berhubungan Dengan Perilaku Seksual Berisiko Pada Remaja Binaan Rumah Singgah. Jurnal Keperawatan Indonesia, 20(3), 185-194.

https://doi.org/10.7454/jki.v20i3 .623

Viner, R. M., Allen, N. B., \& Patton, G. C. (2017). Puberty, Developmental Processes, and Health Interventions. In Child and Adolescent Health and Development (Third Edit). The World Bank. https://doi.org/10.1596/978-14648-0423-6/pt2.ch9

Wraw, C., Der, G., Gale, C. R., \& Deary, I. J. (2018). Intelligence in youth and health behaviours in middle age. Intelligence, 69, 7186.

https://doi.org/10.1016/j.intell.2 018.04.005 